\title{
A Vicious Circle in Lateral Elbow Tendinopathy Mechanism and a Novel Exercise Method
}

\section{Lateral Dirsek Tendinopati Mekanizmasında Kısır Döngü ve Yeni Bir Egzersiz Yöntemi}

${ }^{1}$ Necmettin Erbakan University, Meram Faculty of Medicine, Department of Orthopaedics and Traumatology, Konya, Turkey

${ }^{2}$ Necmettin Erbakan University, Meram Medical Faculty, Department of Neurology, Konya, Turkey

${ }^{3}$ Necmettin Erbakan University, Meram Faculty of Medicine, Department of Physical Treatment and Rehabilitation, Konya, Turkey ${ }^{4}$ Necmettin Erbakan University, Meram Faculty of Medicine, Department of Medical Education and Informatics, Konya, Turkey

\section{Address correspondence to: Ismail Hakki} Korucu, Necmettin Erbakan University, Meram Faculty of Medicine, Department of Orthopaedics and Traumatology, Konya, Turkey

e-mail: drihkorucu@gmail.com

Geliş Tarihi/Received: 26 October 2021 Kabul Tarihi/Accepted: 30 November 2021

\begin{abstract}
$\ddot{O z}$
Amaç: Lateral dirsek tendinopatisi öncelikle ekstansör digitorum communis, ekstansör karpi radialis brevis ve ekstansör karpi ulnaris kaslarının ekstansör disfonksiyonu ile ilişkilidir.Ekstansör karpi radialis brevis ve ekstansör karpi ulnarisin ikincil işlevleri, sırasıyla bileğin radyal ve ulnar deviasyon hareketidir. Bileğin (radio-ulnar) bu antagonistik kuvveti nedeniyle bir kısır döngü olarak ortak ekstansör tendonun tam olarak dinlenemeyeceğini varsaydık. Bu çalışmada tam iyileşmeyi engelleyen kronik persistan patofizyolojik mekanizmayı açıklamayı ve bu yeni egzersiz yönteminin sonuçlarını sunmayı amaçladık.

Hastalar ve Yöntem: 2015-2016 yılları arasında 47 LET hastası (egzersiz: 27; kontrol: 20) vaka kontrol çalışmasına dahil edildi. Egzersiz, egzersiz grubu için ulnar-radial deviasyondan oluşuyordu. Hasta dereceli tenisçi dirseği değerlendirme (PRTEE) testi başlangıç, 1., 6. ve 12. aylardaki ölçümler için kullanıldı. İki grubun bu puanlarını karşılaştırmak için karma modeller kullanıldı.

Bulgular: Egzersiz ve kontrol gruplarının PRTE başlangıç puanları arasında fark yoktu (t:-0.22, p:0.830). 1., 6. ve 12. aylardaki PRTE puanları, egzersiz grubunda kontrollere göre anlamlı olarak daha düşüktü (t: -3.71 , p: $0.0003 ; \mathrm{t}:-3.88, \mathrm{p}: 0.0002 ; \mathrm{t}:-2.28, \mathrm{p}: 0.024$, sırasıyla).

Sonuç: Ortak ekstansör tendon bu antagonistik kuvvet nedeniyle tam olarak dinlenemez. Tendon üzerindeki antagonistik gerilimi azaltmayı amaçlayan egzersiz yönteminin, uzun süreli inflamasyon ve/ veya tendinoz mekanizmasının anlaşılmasına katkı sağlayabilecek etkili olduğu bulundu.

Anahtar Kelimeler: Tenisçi dirseği, ekstansor tendon, lateral epikondilit

\section{Abstract}

Aim: Lateral elbow tendinopathy is primarily associated with an extensor dysfunction of extensor digitorum communis, extensor carpi radialis brevis and extensor carpi ulnaris muscles. The secondary functions of extensor carpi radialis brevis and extensor carpi ulnaris are radial and ulnar deviation movement of the wrist, respectively. We hypothesized that common extensor tendon cannot fully rest, due to this antagonistic strength of wrist (radio-ulnar) as a vicious circle. We aimed to explain the chronic persistent pathophysiological mechanism that prevented complete recovery and to present results of this novel exercise method in the study.

Patients and Methods: 47 LET patients (exercise: 27; control: 20) were included in the case-control study between 2015 and 2016 . The exercise consisted of ulnar to radial deviation for the exercise group. The patient-rated tennis elbow evaluation (PRTEE) test was used for measurements at baseline, 1st , 6th, and 12 th months. Mixed models were used to compare these scores of the two groups.

Results: There was no difference between the PRTEE baseline scores of the exercise and control groups $(\mathrm{t}:-0.22, \mathrm{p}: 0.830)$. The PRTEE scores in the $1 \mathrm{st}, 6 \mathrm{th}$, and 12th months were significantly lower in the exercise group than in the controls ( $t:-3.71, p: 0.0003 ; t:-3.88, p: 0.0002 ; t:-2.28, p: 0.024$, respectively). Conclusion: Common extensor tendon cannot fully rest, due to this antagonistic strength. The exercise method, which aims to decrease the antagonistic tension on the tendon, was found to be effective, which may contribute to understand the prolonged inflammation and/or tendinosis mechanism.
\end{abstract}

Key words: Tennis elbow, common extensor tendon, lateral epicondylitis
Cite this article as: Korucu IH, Tokgoz OS, Kucuksen S, Kir HH, Iyisoy MS. A Vicious Circle in Lateral Elbow Tendinopathy Mechanism and a Novel Exercise Method. Selcuk Med J 2021;37(4): 359-364
Disclosure: None of the authors has a financial interest in any of the products, devices, or drugs mentioned in this article. The research was not sponsored by an outside organization. All authors have agreed to allow full access to the primary data and to allow the journal to review the data if requested. 


\section{INTRODUCTION}

Lateral elbow tendinopathy (LET) is a common musculoskeletal injury, with the prevalence being 30\% in some working populations such as tennis players but $1 \%$ in the general population $(1,2)$. Exercise programme is the most common treatment for the management of LET (3). Concurrently, the exercise programme is combined with other medical modalities such as extracorporeal shockwave therapy (ESWT), acupuncture, steroids and platelet-rich plasma (PRP). However, the optimal protocol of the exercise programme remains still unknown $(3,4)$. In the absence of a clear description of the pathophysiological mechanism, the treatment modalities, especially exercise approaches, have been found to be still ineffective, and symptoms may last from 6 months to 2 years $(2,5,6)$.

We examined a patient who underwent several unsuccessful treatment approaches, including antiinflammatory drugs, standard exercise programmes, ECSWT and PRP for LET treatment. The patient found a novel exercise method to release his increased tension of the common extensor tendon (CET). The exercise was effective in providing relief from pain within a minute. In the light of this case, we aimed to explain the chronic persistent pathophysiological mechanism that prevented complete recovery and to present results of this novel exercise method in the study.

\section{PATIENTS AND METHODS}

This was a hospital-based prospective casecontrol study conducted on 47 patients with LET between 2015 and 2016. Written consent form was obtained from all patients, and the study was performed according to the Declaration of Helsinki. Ethic approval code: 2015/396.

Inclusion criteria: Patients with LET symptoms lasting for more than 2 months and those who had taken any treatment in the past and were not under any treatment currently were included in the study (Figure 1).

Exclusion criteria: Patients with radial tunnel syndrome, cervical radiculopathy, rotator cuff syndrome, radial collateral ligament injury, distal biceps pathology, posterior interosseous nerve syndrome, brachial plexopathy and acute LET (until a month) were excluded from the study (Figure 1). All patients were diagnosed based on the following tests: the lateral epicondyle palpation is painful in all patients, the elbow pain became worse with resisted

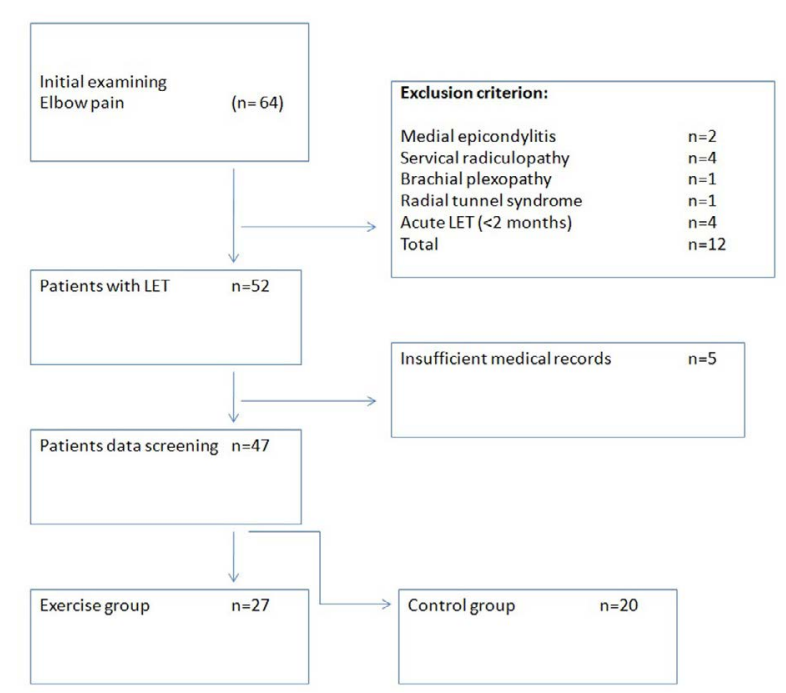

Figure 1. The study flow charts.

wrist extension with pronation (Cozen's test), passive wrist flexion (Mill's test) and directly activating the extensor digitorum communis (Maudsley's test) by resisting third digit extension(7).

\section{Study protocol}

While patients separate two group we used computer programme in order to randomisation.

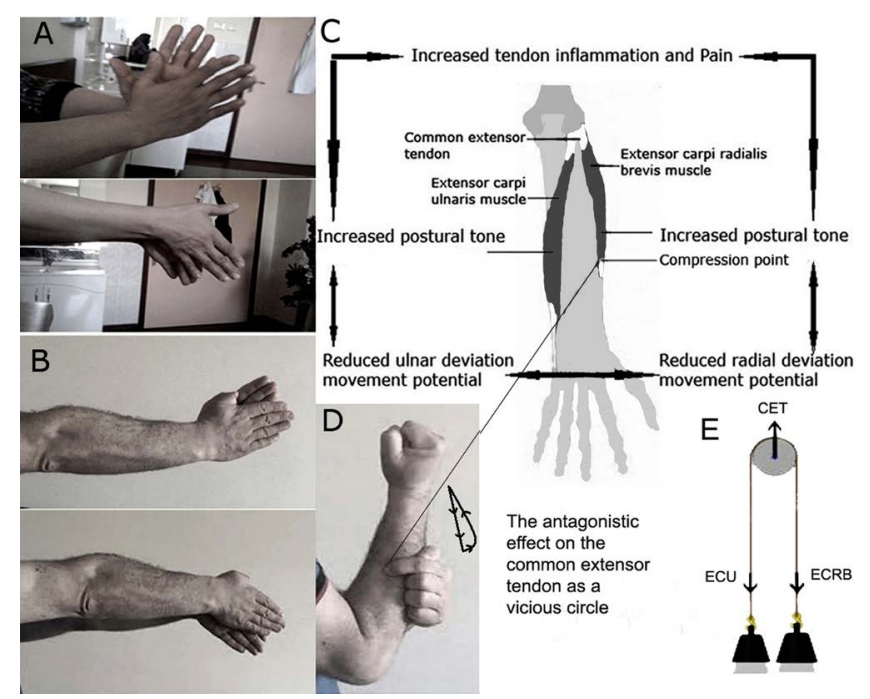

Figure 2. A, B. Two radial-ulnar restriction samples (A: woman, B: man); C, E: A vicious circle on the CET; D: the exercise position, the compression point and the movement trajectory (from ulnar deviation to radial deviation and then slight extension). CET; common extensor tendon, ECRB; extensor carpi radialis brevis, ECU; extensor carpi ulnaris. 


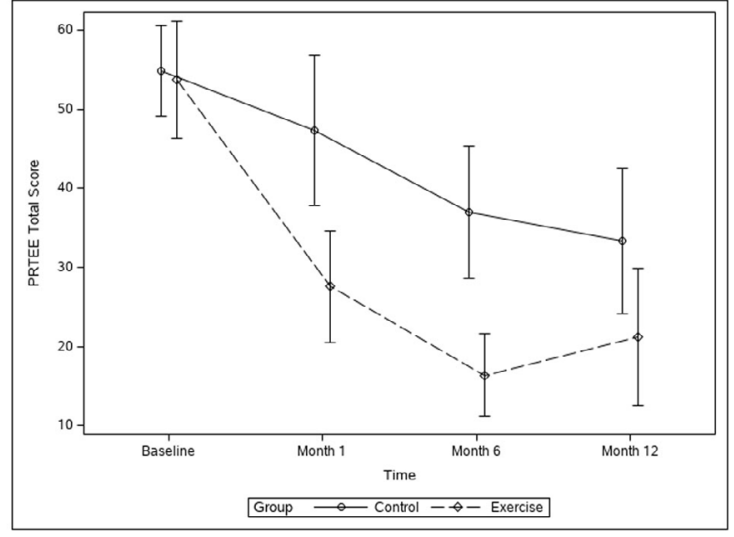

Figure 3. Group-time interaction between the exercise and the control groups. The PRTEE score was lower in the exercise group than in the control group at the end of the first year $(p<0.05)$.

1. The exercise method for the exercise group ( $\mathrm{n}$ $=27$ ): In the elbow flexion position, the patient has to find a painful point on the extensor carpi radialis brevis (ECRB) distal musculo-tendon junction. Then, while the other hand's finger compresses to the distal painful point, the wrist moves powerfully from ulnar deviation to radial deviation, followed by slight extension (Figure $2 \mathrm{D}$, supplemental file 1). This exercise method can be applied for 8-10 times within $1 \mathrm{~min}$, with a frequency of six times a day. In addition, this stretching exercise of the affected arm should be performed before and after any work and whenever the patient feels pain in the elbows.

2. The control group $(n=23)$ avoided movements of the strong extensor, supinator and pronator wrist muscles for a year. Three patients who underwent steroid and PRP injections within a year were excluded from the study. Twenty patients were included in the study as a control group. The patient-rated tennis elbow evaluation (PRTEE) includes assessments of pain level (rest, repeated arm movement, carrying a plastic bag of groceries, its least and its worst) and functional disability level (specific and usual activities such as turning a key, carrying a grocery bag, lifting a full coffee cup to the mouth, opening a jar, pulling up pants, wringing out a washcloth, personal activities and household work, everyday work and sporting activities) (8). The PRTEE test was applied to patients at the onset of pain and after 1 month for the two groups (Table 1). A total score of PRTEE = pain subscale + function subscale (pain and disability contribute equally to score, best score $=0$, worst score =100). The PRTEE score changes were compared in both groups at baseline and the end of 1 st ,6th , and 12th months.

Statistical analysis: Continuous variables are represented by mean \pm standard deviation or median (95\% confidence interval, Cl). Categorical variables are represented by frequencies and percentages. Mixed models were used to compare the baseline, 1,6 , and 12th month scores of the exercise and control groups. A P value $<0.05$ was considered as statistically significant. All analyses were performed using SAS University Edition 9.4 (SAS Institute, Cary, NC).

\section{The exercise method video.}

\section{RESULTS}

A total of 47 patients diagnosed with LET were included in this study. The mean age of the patients was $42.43 \pm 7.94$ years. The demographic data of all patients are reported in Table 1. Patients experienced hand functional disability and pain on the lateral epicondyle. All patients had received a variety of treatment modalities such as anti-inflammatory drugs,

Table 1. Demographic characteristics of the exercise and control group.

\begin{tabular}{|c|c|c|c|c|}
\hline & $\begin{array}{l}\text { Exercise group } \\
(n=27)\end{array}$ & $\begin{array}{l}\text { Control group } \\
(n=20)\end{array}$ & $\mathbf{P}$ & $x^{2} / Z$ \\
\hline Age & $45.42 \pm 7.07$ & $41.25 \pm 12.20$ & $0.004^{*}$ & -2.856 \\
\hline Female & $17(63.0 \%)$ & $9(45.0 \%)$ & 0.23 & 1.468 \\
\hline Right elbow & $20(74.1 \%)$ & $14(70.0 \%)$ & 0.76 & 0.95 \\
\hline Duration of disease history (month) & $8.67 \pm 6.03$ & $9.45 \pm 6.15$ & 0.63 & -0.476 \\
\hline Restriction on radial-ulnar deviation & $8(29.6 \%)$ & $5(25.0 \%)$ & 0.73 & 0.123 \\
\hline The increased pain during radial-ulnar deviation & $15(55.6 \%)$ & $11(40.0 \%)$ & 0.30 & 1.089 \\
\hline Anti-inflammatory drugs & $25(92.6 \%)$ & $20(100 \%)$ & 0.22 & 1.514 \\
\hline Shockwave & $5(18.5 \%)$ & $6(30.0 \%)$ & 0.36 & 0.826 \\
\hline Platelet-rich plasma & $4(14.8 \%)$ & $5(25.0 \%)$ & 0.39 & 0.753 \\
\hline
\end{tabular}


Table 2. (Simple Effect Comparisons of Group*Time Least Squares Means By Time)

\begin{tabular}{lcccc}
\hline Time & $\begin{array}{c}\text { Exercise group } \\
(\mathbf{n = 2 7})\end{array}$ & $\begin{array}{c}\text { Control group } \\
(\mathbf{n = 2 0})\end{array}$ & $\mathbf{t}$ & $\mathbf{P}$ \\
\hline Baseline Total PRTEE & 53,70 & 54.85 & 0.830 & -0.22 \\
$(95 \% \mathrm{CI})$ & $(46,41-60,83)$ & $(49,73-60,02)$ & & -3.71 \\
Month 1Total PRTEE & 27.59 & 47.33 & 0.0003 & \\
$(95 \% \mathrm{CI})$ & $(21,4-34,4)$ & $(38,93-55,86)$ & & -3.88 \\
Month 6 Total PRTEE & 16.33 & 36.95 & 0.0002 & -2.28 \\
$(95 \% \mathrm{CI})$ & $(11,85-21,71)$ & $(29,18-44,87)$ & & \\
Month 12 Total PRTEE & 21.17 & 33.30 & 0.0240 & \\
$(95 \% \mathrm{Cl})$ & $(12,73-29,08)$ & $(24,94-42,23)$ & & \\
\hline
\end{tabular}

PRTEE: The patient-rated tennis elbow evaluation (100/100: 0: normal, 100: severe).

PRP and classical exercise programmes according to their past medical history (Table 1). The baseline PRTEE score was calculated for all patients (Table $1)$. In the exercise and control groups, a movement restriction of the wrist $(n=8 ; 29.6 \% ; n=5,25.0 \%$, respectively) and/or pain on the CET ( $n=15 ; 55.6 \%$; $\mathrm{n}=11,40.0 \%$, respectively) was detected during radial-ulnar deviation movements in some patients, in addition to the classical LET findings, (Figure 2 A,B; Table 1). There was no significant relationship between the radial-ulnar deviation restriction of wrist and the basal PRTEE score ( $z$ : $-1.166 ; P=0.244)$, but the increased pain during radial-ulnar deviation resulted in a significantly higher basal PRTEE score $(60.18,95 \% \mathrm{Cl}: 52.70-67.83)$ than that with no increased pain $(48.92,95 \% \mathrm{Cl}: 44.20-53.24)$ during radial-ulnar deviation $(z=-2.388, P=0.017)$. All patients also complained the increased pain during the wrist extension accompanied by abduction of their all fingers.

In this study, 27 patients were included in the exercise group and 20 patients in the control group. All patients achieved partial relief from the pain within 1 min, but there was recurrence after a few minutes, especially in the rest position in the exercise group.

There was no difference between the PRTEE baseline scores of the exercise and control groups (53.70, 95\% Cl:46,41-60,83; 49.73, 95\%Cl:49,7360,02, t:-0.22, P:0.830, respectively). The PRTEE scores in the 1st,6th, and 12th months were significantly lower in the exercise group than in the control group $(27.59,95 \% \mathrm{Cl}(21,4-34,4), 47,33$ $95 \% \mathrm{Cl} 38,93-55,86$, t: -3.71 , P: 0.0003$)$; (16.33, 95\%Cl: 11.85-21.71; 36.95, 95\%Cl: 29.18-44.87, t: -3.88, P:0.0002); (21.17, 95\%Cl:12.73-29.08; 33.30, 95\%Cl:24.94-42.23, t: $-2.28, \mathrm{P}: 0.024$, respectively) (Table 2, Figure 3).

\section{DISCUSSION}

All patients benefited for this exercise model. The exercise model should be applied in the elbow flexion position, because all patients felt pain in the elbow extension position. This stretching exercise must be performed before and after any work to decrease the tonus of the ECRB and ECU muscles. Moreover, the patients stated that, especially, abduction of the fingers might also result in increased pain in their elbow. The finger abduction movement may cause stretching of the extensor group of muscles under the extensor retinaculum. Movements such as wringing out a washcloth and opening a jar in the PRTEE test also include finger abduction movements as well as radial-ulnar deviation movements, and patients experience increased pain and disability levels in the PRTEE test. Patients with LET complain that the pain, which may radiate distally to the forearm, becomes worse while performing activities involving wrist extension or activation of the CET. The extensor muscle group (ECRB, ECU and extensor digitorum communis) arises from the lateral epicondyle. In the majority of cases, there is tenderness over the ECRB attachment $(1,2)$.

The pathophysiology of LET is still obscure. Nirschl et al classified lateral epicondylitis as follows: Stage 1 , acute inflammation; Stage 2, tendinosis of the tendon with unorganised collagen, angiofibroblastic hyperplasia and vascular hyperplasia; Stage 3, complete or partial rupture of the tendons; and Stage 4, fibrosis, soft tissue and osseous calcifications (9). Histopathological studies have demonstrated that LET is an angiofibroblastic degeneration (tendinosis) rather than an inflammatory process (10). Chronic trauma may cause metabolic changes and microtears in the tendon. Multiple tears in turn result in secondary inflammatory and degenerative reactions, and during the subsequent healing process, a fibroblastic 
tendinosis develops (11).

The following questions need to be answered: What is the reason for chronic trauma? What is the reason for the progression of the pathological process from Stage 1 to Stage 4? Why are several treatments, including anti-inflammatory drugs, PRP, ESWT and physical therapy, sometimes ineffective (12)? Is the rest harmful for the treatment? The trajectory of the movements leading to tendon damage should be examined. The primary function of the extensor muscle group is wrist extension. The extension movement is generally accused, and the extension dysfunction is taken into consideration during examination (Cozen, Mill, Maudsley tests) (7). However, the majority of physicial therapies, including extension function, cannot effectively decrease the tendon damage and treat the condition. Eccentric exercise combined with adjuvant therapy showed beneficial effects with regard to pain reduction and muscle strength improvement.(19) Nevertheless, the rest position is not useful to relieve pain. In contrast, pain becomes worse and worse at rest and during any other movements of the wrist such as extension.

Lateral epicondyle tendinopathy is also known as a tennis elbow. A backhand spin movement in the tennis and the table tennis is another important movement of the tennis elbow mechanism. The backhand spin movement includes so many shoulder, elbow and wrist movements $(13,14)$, but the major strong movement starts from ulnar deviation, continues to radial deviation and ends in slight extension of the wrist, especially in table tennis. We applied this trajectory of this movement for the physical therapy in our study (Figure $2 \mathrm{D}$ ). Movements such as wringing out a washcloth and opening a jar also involve the radial-ulnar deviation movement of the wrist as well as extension and supinasyon movements in the PRTEE test, which is similar to the our exercise model. The movements of the wrist are the dominant and mutual movements of both tennis-players and non-tennisplayers LET patients, rather than shoulder and elbow movements.

The extensor carpi ulnaris (ECU) muscle, belonging to the extensor muscle group, is also responsible for ulnar deviation of the wrist as well as extension, whereas the ECRB muscle participates in radial deviation function of the wrist as well as extension. These two muscles arise from the same origin (the lateral epicondyle), but they are also responsible for the wrist opposite deviations (Figure 2). This issue may be important in LET pathophysiology, because the wrist radial-ulnar deviation restriction and/or pain, as well as the classical LET findings, were detected in our patients. Tendinitis and/or tendinosis of the lateral epicondyle tendon may cause relaxation failure of the ECU and ECRB as well as the extensor digitorum communis. These increased postural tone and strength of these muscles (for radial-ulnar deviations) may result in increased tension on the CET, by pulling the opposite sides, in both the rest position and any radial-ulnar deviation activities of the wrist. As each muscle contracts, the other muscles cannot relax, and pain exaggerates as a vicious circle (Figure $2 \mathrm{C}$, $E)$. This condition may be the reason for chronic and prolonged trauma. This issue could explain that there is strong evidence suggesting discordance between tendon pathology and clinical severity in patients with tendinopathy $(7,15-17)$.

In the light of this pathophysiology, we can understand the reason for the less effectiveness of the several treatment modalities. Until recent years, LET was believed to be only an inflammatory process, and treatment was aimed at combating this presumed inflammatory process. However, the treatment itself has been inadequate $(5,8)$. We believe that the anti-inflammatory treatment and the other treatment modalities are more effective when the CET tension along with an appropriate exercise programme decreases. An aim of the compression on the ECRB distal tendon is to make fixation and prevent exerciseinduced tension on the CET (Figure 2 D). On the other hand, this compression and stretching may also activate Golgi tendon organ sensors (1b fiber), which require considerable force. These sensors synapse on interneurons in the spinal cord, which inhibits the activity of the motor neurons innervating the ECRB. This relaxation prevents damage from excessive force (18). As a result; the rehabilitation of the intact tendon instead of the damaged tendon may be more useful to resolve spasm. Therefore, this exercise method may help relax both the ECU and ECRB muscles, which decreases the postural tone and the antagonistic tension on the CET. We presume that the other exercise models cannot be useful in treating LET, as long as the antagonistic tension is present.

\section{Limitations}

This study included a small sample of patients. There was no homogenous distribution in terms of age between the exercise and control groups (Table 1). We did not use electroneuromyography (ENMG) in material method for detecting antagonistic strength and for showing the exercise-effect. The participants 
suffered from more pain at the neutral rest position than the flexion position of elbow and they feel more pain during the wrist movement with fingers abduction position. We haven't got any data for these findings, so that they stayed out subjective.

In conclusion, radio-ulnar deviation movement rather than extension of wrist is one of the major movements in PRTEE test materials such as open a jar, wring out a washcloth or wet towel, which is similar to our exercise model. We focused our attention on this secondary function of the ECU and ECRB muscles. We believe that the opposite strength on the CET, which is created by the increased tone of the ECRB and ECU, is another important issue, as well as the extension dysfunction, for understanding the pathophysiology and treatment. CET cannot fully rest, due to this antagonistic strength. Therefore, the tendinitis and/or tendinosis and pain become worse at rest and during any other movements of the wrist as a vicious circle, which causes continuous trauma. This topic is the most important issue for this manuscript, rather than the effective treatment. This issue might be considering for the choice of the exercise in controlled studies. This novel exercise method may decrease the opposite tendon tension and assist other treatment modalities. Studies evaluating the acute term (Stage 1) using this method are needed to detect whether total recovery may occur without tendinosis. We think that this treatment should be started immediately to resolve the antagonistic spasm at the begining of the disease. A similar antagonistic paradigm may be present in medial epicondylitis, because the flexor carpi ulnaris and flexor carpi radialis muscles adhere to the same tendon.

Conflict of interest: Authors declare that there is no conflict of interest between the authors of the article.

Financial conflict of interest: Authors declare that they did not receive any financial support in this study.

Address correspondence to: Ismail Hakki Korucu, Necmettin Erbakan University, Meram Faculty of Medicine, Department of Orthopaedics and Traumatology, Konya, Turkey.

e-mail: drihkorucu@gmail.com

\section{REFERENCES}

1. Heales LJ, Broadhurst N, Mellor R, et al. Diagnostic ultrasound imaging for lateral epicondylalgia: A case-control study. Med Sci Sports Exerc 2014;46:2070-6.

2. Thompson C, Visco C. Lateral epicondylosis: Emerging management options. Curr Sports Med Rep 2015;14:215-20.
3. Ahmad Z, Siddiqui N, Malik SS, et al. Lateral epicondylitis: A review of pathology, and management. Bone Joint $\mathrm{J}$ 2013;95:1158-64.

4. Dimitrios S. Lateral elbow tendinopathy. Evidence of physiotherapy management. World J Orthop 2016;7:463-6.

5. Coombes BK, Bisset L, Vicenzino B. Management of Lateral elbow tendinopathy: One size does not fit all. J Orthop Sports Phys Ther 2015;45:938-49.

6. Bostan B, Balta $\mathrm{O}, \mathrm{Aşçı} \mathrm{M,} \mathrm{et} \mathrm{al.} \mathrm{Autologous} \mathrm{blood} \mathrm{injection}$ Works for recalcitrant lateral epicondylitis. Balkan Med J 2016;33:216-20.

7. Fairbank SM, Corlett RJ. The role of the extensor digitorum communis muscle in lateral epicondylitis. J Hand Surg $\mathrm{Br}$ 20012;27:405-9.

8. Bisset LM, Vicenzino B. Physiotherapy manegement of lateral epicondylalgia. J Physiother 2015;61:174-81.

9. Nirschl RP. Prevention and treatment of elbow and shoulder injuries in the tennis player. Clin Sports Med 2018;7:289-308.

10. Nirschl RP. Elbow tendinosis/tennis elbow. Clin Sports Med1992;11:851-70.

11. Kraushaar BS, Nirschl RP. Curret concepts review tendinosis of the elbow (Tennis Elbow). J Bone Joint Surg Am 1999;81:259-78.

12. Guler NS, Sargin S, Sahin N. Efficacy of extracorporeal shockwave therapy in patients with lateral epicondylitis: A randomized, placebo-controlled, double-blind clinical trial. North Clin Istanb 2018;5:314-318.

13. Genevois C. Reid M. Roqowski I, et al. Performance factors related to the different tennis backhand groundstrokes: A review. J Sports Sci Med 2015;14:194-202.

14. Nesbit SM, Elzinga M, Herchenroder C, et al. The effects of racket inertia tensor on elbow loadings and racket behavior for central and eccentric impacts. J Sports Sci Med 2016; 5:304-17.

15. du Toit C, Stieler M, Saunders R, et al. Diagnostic accuracy of power doppler ultrasound in patients with chronic tennis elbow. Br J Sports Med 2018;42:872-6.

16. Fan ZJ, Silverstein BA, Bao S, et al. The association between combination of hand force and forearm posture and incidence of lateral epicondylitis in a working population. Hum Factors 2014;56:151-65.

17. Takasak iH, Aoki M, Muraki T, et al. Muscle strain on the radial wrist extensors during motion-simulating stretching exercises for lateral epicondylitis: A cadaveric study. J Shoulder Elbow Surg 2007; 16:854-8.

18. Marani E, Lakke EAJF. Peripheral nervous system topics. In Mai JK, Paxinos G (eds). The human nervous system. 3rd edition. Elsevier 2011:123.10.1016/j.jval.2015.09.2358.

19. Yoon SY, Kim YW, Shin IS, et al. The beneficial effects of eccentric exercise in the management of lateral elbow tendinopathy: A systematic review and meta-analysis. J Clin Med 2021;10(17):3968. 